\title{
Innovation policies in transition countries: one size fits all?
}

\author{
Reinhilde Veugelers ${ }^{1,2} \cdot$ Helena Schweiger $^{3}$
}

\begin{abstract}
Transition countries are at different stages of development and firms in these countries vary in their use and creation of knowledge for growth. This is shaped by varying conditions in the countries that allow firms to access, absorb and create new technologies. Policies designed to support innovation need to take these individual circumstances into account. However, analysis reveals that innovation policies across the transition region are surprisingly similar, characterised by an excessive focus on the creation of technology, particularly from public funded research organisations and insufficient attention to the absorption of technology by the private sector. Innovation policies in transition countries would gain from better governance, more sophisticated public administrations and private-sector involvement.
\end{abstract}

Keywords Transition countries · Innovation · Innovation policy

JEL Classification $\mathrm{P} 20 \cdot \mathrm{O} 30 \cdot \mathrm{O} 38$

\begin{abstract}
This article draws heavily on the EBRD Transition Report 2014: Innovation in Transition, Chapter 5. We would like to thank Erik Berglöf, Martin Bruncko, Ralph de Haas, Sergei Guriev and Alexander Plekhanov for helpful discussions and Giulia Bovini, Olga Gladuniak and Alexander Stepanov for excellent research assistance. The views expressed in this article are our own and do not necessarily represent those of the institutions of affiliation.
\end{abstract}

Reinhilde Veugelers

Reinhilde.veugelers@kuleuven.be

Helena Schweiger

schweigh@ebrd.com

1 KU Leuven, Leuven, Belgium

2 Bruegel, Brussels, Belgium

3 European Bank for Reconstruction and Development, London, UK 


\section{Introduction}

Governments everywhere acknowledge the importance of innovation for long-term growth. This is most noticeable in countries where the easy options have been exhausted and future growth depends on more efficient ways of combining inputs or producing new or improved outputs.

Governments can foster innovation indirectly by providing a suitable environment for firms that are willing to invest and innovate. They can also support innovation directly, by either funding public research or encouraging private investment in research and innovation (for example through innovation-related tax incentives or grants). Often policy options favour one sector over another, and some sectors may require specific interventions. This requires governments to make difficult choices, striking a balance between improvements in the general environment for innovation and direct support for innovation, targeted or not to specific (groups of) actors.

The combination of policy objectives and instruments should be tailored to a country's level of development and the strengths and weaknesses of its innovation system, so it should vary both across countries and over time.

In this article, we focus on the countries in Eastern Europe and Central Asia, including Mongolia (transition countries). ${ }^{1}$ At the start of the transition process, countries in the transition region generally had unusually low levels of total factor productivity, reflecting the inefficient allocation of resources under central planning. When production factors began to be redeployed more efficiently (through laying off excess workers, cutting other costs and improving the use of capacity), total factor productivity initially grew rapidly. However, by the time of the global financial crisis, productivity in the region had reached the levels seen in other emerging markets with similar income levels. This suggests that most of the easy options have now been exhausted (EBRD 2013, 2014). Further improvements in productivity will need to come from structural changes in these economies-in other words, changes to their economic structure and economic institutions, as well as policies supporting reforms and the development of human capital. Science, technology and innovation policies (henceforth simply referred to as "innovation policies") form an integral part of this process.

Although some of these countries have made important technological breakthroughs in the past—-such as Sputnik 1, the first artificial satellite to orbit the Earth, and Vostok 1, the world's first manned spacecraft-they are not currently operating at the technological frontier in most areas. Instead, they are at various stages of the catching-up process. Furthermore, the legacy of centrally planned innovation systems still looms large over much of the transition region-particularly in the countries of the former Soviet Union, where most research work was conducted by special research institutes rather than universities or private companies. Although

\footnotetext{
${ }^{1}$ Unless stated otherwise, the analysis includes the following countries: Albania, Armenia, Azerbaijan, Belarus, Bosnia and Herzegovina, Bulgaria, Croatia, Czech Republic, Estonia, FYR Macedonia, Georgia, Hungary, Kazakhstan, Kosovo, Kyrgyz Republic, Latvia, Lithuania, Moldova, Mongolia, Montenegro, Poland, Romania, Russia, Serbia, Slovak Republic, Slovenia, Tajikistan, Turkmenistan, Ukraine and Uzbekistan.
} 
the pure science and innovation that resulted from those top-down systems were sometimes very advanced, they often failed to translate into commercially viable applications, as links with industry were weak. While there are examples of innovative companies subsequently emerging from these environments, the interface between research and the rest of the economy remains rudimentary at best.

With this in mind, this article provides an overview of innovation policies in transition countries and assesses their appropriateness given the level of development in these countries. It first provides an overview of the relevant literature and analyses the potential for transition countries to follow a knowledge-based growth path, given their current position in terms of innovation and framework conditions for innovation-based growth. It then discusses the main characteristics of the innovation policies currently being pursued, assessing whether the policies are in line with the countries' level of development and their potential for innovationbased growth. It concludes by providing guidelines for more appropriate and differentiated innovation policies.

\section{Stages of innovation development and innovation policies along the development path}

\subsection{Stages of innovation development: a review of the literature}

Which country-specific factors are important as drivers of innovation varies depending on a country's position relative to the global technological frontier-in other words, whether a country is in a pre-catching-up phase, a catching-up phase or a post-catching-up phase (Verspagen 1991).

In economies with very low levels of development, take-up of technology is absent or slow, in part because of the cost of new technologies and in part because insufficient human capital severely constrains technological progress. As development kicks off, however, the pace of technology take-up starts to vary greatly, even across countries at similar levels of development (World Bank 2008). One explanation for this heterogeneity in take-up rates is the difference in the countries' ability to effectively absorb new technologies (Lall 1992).

There are two key ingredients for effective technology take-up. The first is access to (foreign) technology, particularly access to Information and Communication Technology (ICT). Trade flows, foreign direct investment (FDI) and other forms of international cooperation are the key channels that determine how successful a country will be in tapping the global pool of existing technologies (see, e.g., Blomström and Kokko 1998; Keller, 2004). ${ }^{2}$ Second, the effectiveness of these channels for effective technology take-up depends on a country's absorptive capacity. External (foreign) knowledge needs to be combined with a sufficiently

\footnotetext{
2 That being said, trade protection has been used by several countries that were successful in catching up in the nineteenth and twentieth centuries, including Germany, Japan and South Korea (Mazzoleni and Nelson 2007), and initial tariffs for skill-intensive industries have been found to be positively correlated with long-term growth in GDP per capita (Nunn and Trefler 2010).
} 
developed 'absorptive capacity' (Cohen and Levinthal 1989) or 'social capability' (Abramovitz 1986) in order to deliver growth.

This absorptive capacity depends on many factors, including the extent to which a country has a technologically literate workforce and a highly skilled elite, promotes a pro-investment climate, permits the creation and expansion of firms using higher-technology processes, permits access to capital and has adequate public-sector institutions to promote the take-up of critical technologies when private demand or market forces prove inadequate (World Bank 2008).

As countries develop further and get closer to the technology frontier, another factor that explains the heterogeneity of technology take-up comes into playnamely divergence in countries' own indigenous innovative capacity (Hoekman et al. 2005). First, a country's own R\&D complements the take-up of existing technology because it is a component of absorptive capacity. Foreign technologies frequently need to be modified so that they are suitable for domestic circumstances (Acemoğlu et al. 2006). Countries tend to acquire technology more readily when domestic firms have R\&D programmes and when public research laboratories and universities have relatively close ties to industry. But, at higher levels of development, a country's own R\&D can increasingly substitute adoption of existing technologies, allowing the generation of new technologies, particularly in sectors in which the country has developed some comparative strengths.

At this stage, countries require technological know-how, mostly in the form of public and private $R \& D$ resources. They also need to be able to incentivise or reward innovation (see, e.g., Furman et al. 2002). This requires well-functioning product markets that are sufficiently open to competition. This also requires a large base of local or foreign customers willing to pay for innovative products and effective intellectual property rights (IPR) schemes as well as the presence of skills and well-functioning labour markets that give innovators access to researchers and skilled human capital. Similarly, well-functioning (risk) capital markets give innovators access to capital to finance their risky projects.

\subsection{Stages of innovation development: a review of the evidence}

Empirical research confirms the importance of technological progress for development (see, e.g., Nelson 1993; RINDICATE 2007). Fagerberg et al. (2007) and Fagerberg and Srholec (2008) find technological capacity, along with governance and quality of institutions, to be significantly related to growth for a large crosssection of developing countries.

The empirical evidence on the effects of international technology transfers for development is less clear cut (Hoekman and Smarzynska Javorcik 2006). Studies using panel data sets, correcting for firm- or sector-specific fixed effects, find no positive within-industry spillover effects on the growth and productivity of local firms for countries in development. This is accounted for by the lack of absorptive capacity in these countries (see, e.g., Aitken and Harrison 1999; Blomström and Kokko 1998; Narula and Dunning 2000; Damijan et al. 2003). An additional explanation for the lack of evidence of positive intra-industry spillovers from openness is the confounding impact of competitive effects from open markets 
(Markusen and Venables 1999). More positive results are found for cross-industry spillovers of the vertical type (see, e.g., Görg and Greenaway 2004).

\subsection{Innovation development in transition countries}

Specific transition process patterns have strongly influenced the overall development during the last two decades in the countries studied in this article, with implications for their innovation-based growth. Dyker and Radošević (1999) performed a thorough analysis of the transformation process that former communist countries have undergone since the beginning of their transition. Their in-depth examination of the restructuring process that has reshaped science and technology in these countries clearly points out that this transformation has been strongly linked to the industrial restructuring and to the general economic and social changes that have accompanied transition.

A large empirical literature has developed, examining the factors that influence the growth of companies in transition countries (see, e.g., RINDICATE 2007). Most of these studies make use of the European Bank for Reconstruction and Development (EBRD)-World Bank (WB) Business Environment and Enterprise Performance Survey (BEEPS). Most of these empirical firm-level studies find that factors driving growth are highly interlinked, suggesting the importance of a systemic approach to structural reform. Carlin et al. (2004), in particular, look at the relationship among competition, finance, innovation and growth in transition economies. They show that competitive pressures increase innovation in both new and incumbent firms, subject to hard budget constraints for incumbent firms and availability of financing for new firms. Moreover, Gorodnichenko et al. (2010) show that the impact of competition on innovation depends on the technology position of the firms. They confirm the importance of trade and FDI, especially vertical transfers of capabilities in multinational supply chains.

To summarise, technological progress through technology absorption and/or creation can be an important driver for development, but is no guarantee of success. Depending on the country's initial level of development, a set of additional factors, shaping the country's capacity for a virtuous innovation-growth link, needs to be present. In addition to R\&D, technology and ICT infrastructure, these additional factors include access to large markets, (international) openness of markets, competition, access to a highly educated and skilled population (especially tertiarylevel), well-developed financial markets and, finally, quality institutions and macroeconomic stability. It is important to note that these factors should not be seen in isolation, but as part of a system of key prerequisites for knowledge-based growth.

\subsection{Innovation policies along the development stage}

As discussed in the previous section, transition countries will find different framework conditions-conditions that shape the context in which firms innovate and influence their innovation performance-to be of relevance depending on their stage of innovation development. Furthermore, as countries will be progressing on their path of innovation-based development, different framework conditions will 
become important. Policies that help to improve these conditions must evolve accordingly, depending on the extent to which conditions supporting knowledgebased growth are already in place and which ones need to be in order to progress to the next stage.

Having better access to technology without an educated workforce that is capable of effectively absorbing such technology will make it difficult for countries to progress to the "buy" stage of knowledge acquisition. Countries that become successful at absorbing technology and seek to create knowledge to adapt and create new knowledge will need to improve the availability of specific skills. They will also need to strengthen links between public scientific institutions and the private sector. $^{3}$

Where countries are still in the early stages of technological development, policies should focus on fulfilling the conditions for access to and absorption of technology. In these circumstances, a policy mix that focusses solely on strengthening creative capacity (for instance, through increases in venture capital or grants fostering cooperation between industry and science) may yield only limited results. At the same time, those factors cannot be completely ignored, as elements such as cooperation between industry and science and the quality of scientific research institutions take a long time to build.

\section{Innovation-based development in transition countries}

Before we look at the innovation policies in place in the transition countries under study - and assess their appropriateness-we first characterise the countries on their current stage of innovation development and their positioning on the framework conditions required for an innovation-based growth path.

\subsection{Stages of innovation development}

The transition countries under study differ significantly in terms of their rates of innovation and whether and how firms acquire or create the know-how that they need (EBRD 2014).

Figure 1 shows how countries compare in terms of whether they "make" knowledge (in-house R\&D) or "buy" it (outsourced R\&D, or the purchase or licensing of external knowledge) based on data from the EBRD-WB BEEPS $\mathrm{V}$ in transition countries. The horizontal axis shows the percentage of firms that only buy knowledge, while the vertical axis shows the percentage of firms that only follow a "make" strategy or employ a combination of "make" and "buy" strategies.

On the basis of firms' responses, three broad groups of countries emerge: ${ }^{4}$

\footnotetext{
${ }^{3}$ See Aghion et al. (2009b) for a discussion of specific aspects of human resources, which influence a country's absorptive and creative capacity.

${ }^{4}$ Data on R\&D expenditures in the GDP may result in a different classification, especially in countries where most $R \& D$ is conducted in research institutes and universities. Our focus is on the private sector firms in industries covered by BEEPS/Enterprise Surveys in general (see http://ebrd-beeps.com/ methodology/sector-and-size-coverage/ for more details).
} 


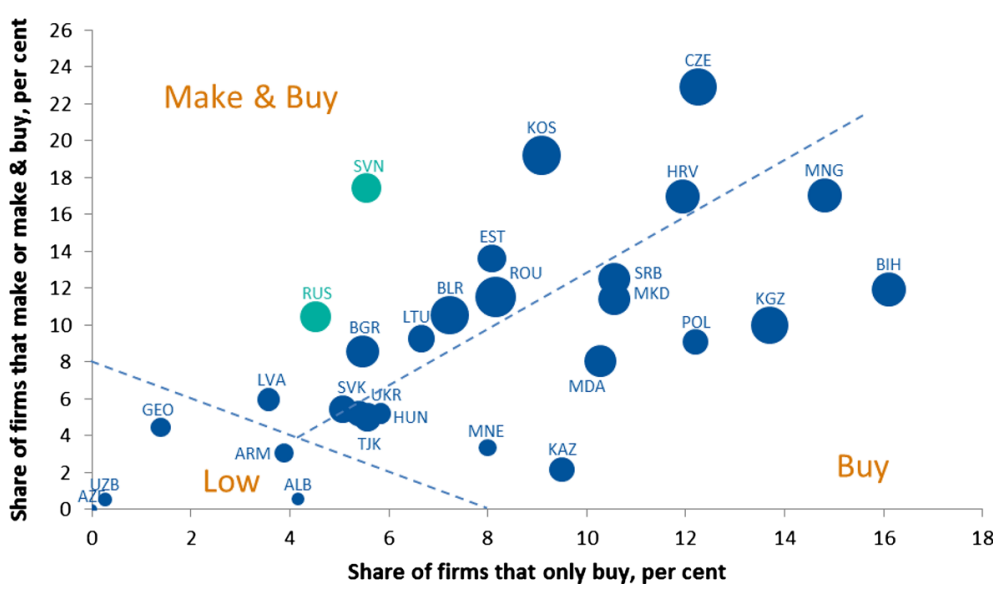

Fig. 1 Percentage of firms that make and/or buy knowledge. Source: BEEPS V and the authors' calculations. Note A "make" category refers to in-house R\&D, whereas a "buy" category refers to outsourced R\&D and the purchase or licensing of patents and know-how. The lighter colour denotes countries where the percentage of firms that only fall into a "make" category is greater than the percentage of firms that only fall into a "buy" category. The size of the bubble corresponds to the percentage of firms that have engaged in product innovation (on the basis of cleaned data). ISO ALPHA-3 country codes are used

1. Low innovation: In this group of countries, located in the bottom left-hand corner of Fig. 1, few firms spend money on buying or producing knowledge. This group includes Albania, Armenia, Azerbaijan, Georgia and Uzbekistan.

2. Buy: Firms in this group of countries predominantly buy technology, with the percentage of firms that engage in in-house $R \& D$ remaining relatively modest. Countries in this category include Bosnia and Herzegovina, FYR Macedonia, Hungary, Kazakhstan, Kyrgyz Republic, Moldova, Mongolia, Montenegro, Poland, Serbia, Tajikistan, Turkey and Ukraine.

3. Make and buy: Firms in this group of countries, which is located above the sloping line, are more active in terms of in-house $R \& D$ relative to the acquisition of external knowledge. This group could be broken down further on the basis of the extent to which firms tend to engage mostly in in-house R\&D or both make and buy knowledge. Most transition country are situated in the latter category: Belarus, Bulgaria, Croatia, Czech Republic, Estonia, Kosovo, Latvia, Lithuania, Romania, Russia, Slovak Republic and Slovenia.

\subsection{Assessment of prerequisites for innovation-based growth in transition countries}

Business environment conditions for innovation include broader business environment conditions (or general framework conditions). Such conditions affect the operations and decisions of all firms in the economy, including firms that innovate. Business environment conditions include the quality of institutions (in other words, 
the legal and administrative framework that underpins interaction among individuals, firms and governments), macroeconomic stability and the functioning of products, labour and financial markets.

Some business environment conditions specifically affect innovative firms. Taking into account differences in levels of development, the conditions influencing innovative capacity can be divided into those affecting access to technology, those affecting firms' capacity to adopt and fully understand existing technologies, and those affecting the ability to create knowledge. Access to technology depends on a country's economic openness, the availability and use of ICT infrastructure and the extent to which openness to FDI and trade facilitates the transfer of technology. Absorptive capacity is underpinned by the quality of secondary and undergraduate education and the effectiveness of on-the-job training, while what matters for creative capacity is the quality of postgraduate education; the availability of highly qualified scientists and engineers; the quality of the public research infrastructure; effective cooperation between public research and industry; the protection of intellectual property and the availability of risk financing. ${ }^{5}$

A simple set of indicators to measure the sets of conditions for innovation-based growth (the quality of institutions; the macroeconomic environment; the functioning of product, finance and labour markets; access to technology; absorptive capacity; creative capacity) is used below to provide a brief assessment of conditions for innovation in individual countries in the transition region.

The exercise measuring the conditions for innovation-based growth in transition countries uses information from the WEF global competitiveness indicators (WEF, 2013). ${ }^{6}$ Data on these indicators are provided not only for the transition countries, but also for a number of advanced economies (countries operating at the technological frontier) and emerging market comparators. Appendix 1 details which WEF indicators are used for proxying each of the framework conditions for innovation. Figure 2 shows the results.

The largest gap between the transition countries and advanced economies relates to the capacity to create knowledge (see Fig. 2a). In this creative capacity pillar, transition countries score relatively well on the availability of scientists and engineers (thanks to the emphasis placed on science and technology in the days of centrally planned economies). They lag behind when it comes to the quality of scientific research institutions and the availability of venture capital.

The gap between transition and advanced economies in terms of their absorptive capacity and access to technology is smaller. Most of the remaining gap is due to the lower availability and use of ICT in transition countries. This is also the area where differences among the countries within the transition region are the largest. This suggests that there are still countries in the region who have not yet fully exploited the potential of ICT to foster innovation-based growth. Lower use of ICT often

\footnotetext{
5 For a more detailed description and explanation of the various prerequisites and their measurement, see Veugelers (2011) and Appendix 1.

6 The World Bank knowledge economy indicators provide a similar assessment, but a less detailed one for the purposes of analysis in this article.
} 

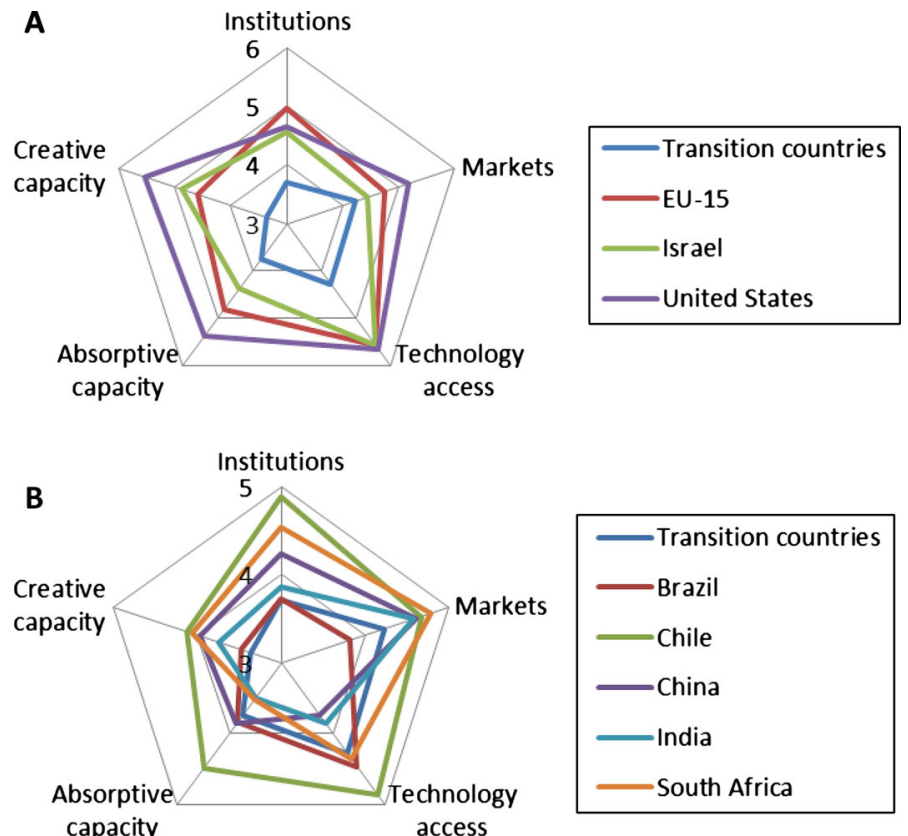

Fig. 2 Assessment of framework conditions in transition countries and comparators. a Advanced industrialised economies. b Emerging markets. Source: Authors' calculations on World Economic Forum (2013). Note The scores for each indicator range from 1 to 7 , where 1 corresponds to the worst possible outcome and 7 corresponds to the best possible outcome. Scores for "macroeconomic stability" are not shown, given the extraordinary circumstances affecting this broad framework condition in the review period. Data are not available for Belarus, Kosovo, Tajikistan, Turkmenistan or Uzbekistan. Figures for the transition region are unweighted cross-country averages

reflects insufficiently dynamic product and labour markets, as well as inadequate university systems not delivering the skills for ICT uptake (Aghion et al. 2009a).

Transition countries perform somewhat better when it comes to broad business environment conditions such as the functioning of markets. The gap in terms of the quality of institutions remains sizeable.

Differences relative to other emerging markets (such as Brazil, Chile, China, India and South Africa) are smaller (see Fig. 2b). However, the transition region is not in the lead on any aspect. Indeed, it trails all of those comparators when it comes to the capacity to create knowledge (where Chile scores highest).

Within the transition region, countries differ substantially in terms of the conditions for innovation. As expected, countries in the "make and buy" group tend to score higher than the "buy" and "low innovation" countries on all conditions (see Fig. 3). In turn, the "buy" countries score higher than the "low innovation" countries on all aspects (with the exception of the quality of institutions, where differences are generally smaller).

These broad trends mask substantial heterogeneity within each group. For instance, Hungary, Poland and Turkey score highest among the countries in the "buy" group, signalling greater potential for innovation-based growth. However, all 


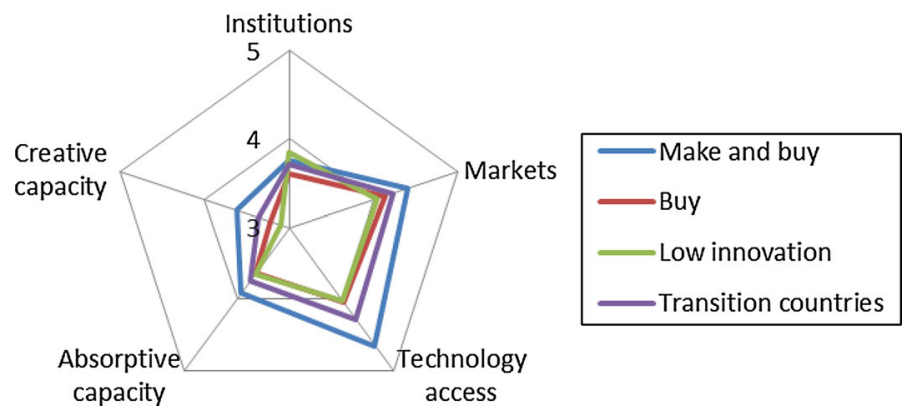

Fig. 3 Framework conditions in transition countries. Source: Authors' calculations on World Economic Forum (2013). Note The scores for each indicator range from 1 to 7, where 1 corresponds to the worst possible outcome and 7 corresponds to the best possible outcome. Scores for "macroeconomic stability" are not shown, given the extraordinary circumstances affecting this broad framework condition in the review period. Data are not available for Belarus, Kosovo, Tajikistan, Turkmenistan or Uzbekistan. Figures are unweighted cross-country averages

of these countries have areas where they underperform. Hungary scores relatively poorly on the quality of institutions and Poland on education; Turkey underperforms when it comes to labour market efficiency and the use of ICT.

Countries in the "low innovation" category have made substantial improvements, particularly in terms of the quality of institutions, access to technology and absorptive capacity. In these areas they have closed all or most of the gap relative to countries in the "buy" category. However, they continue to be held back by insufficient competition in their product markets, as well as their relatively inefficient labour and financial markets.

Regardless of these differences, the fact that transition countries that are more highly developed score better on all conditions for innovation suggests the need to look at the factors for innovation-based growth as a "system". Further developing on innovation requires progress on all indicators. A good illustration of this "systemic" performance is Estonia. It is the best performing country among transition countries. This superior scoring of Estonia holds for all the considered factors (the exception being "size of the domestic market", but this is more than compensated by its better scoring on openness). Relative to the other transition countries in the sample, the superior scoring of Estonia is most notable in its international openness and availability and use of ICT.

Back in the early 1990s Estonia had similar conditions to Latvia and Lithuania, the two other Baltic states, in terms of innovation. ${ }^{7}$ Those countries have since followed separate development paths. Estonia is currently the highest scoring transition country in terms of innovation potential, while Latvia and Lithuania lag some way behind (see Fig. 4).

\footnotetext{
${ }^{7}$ In the Baltic states, the centrally planned system that was previously used to manage and finance science was rapidly dismantled, thanks to the efforts of the scientific unions that launched R\&D reform in 1990. See Kristapsons et al. (2003).
} 


\section{Innovation policies in transition countries: one size fits all?}

Innovation policies can play a crucial role in improving the conditions for innovation, identifying and addressing bottlenecks that impair the ability of countries to innovate and improve productivity. Estonia is a good example of the power of innovation policy. Its stellar performance among transition countries on innovation-based growth rides on its systemic Knowledge-Based Estonia (KBE) innovation policy which it started already at an early stage, in 2000, and continued to develop further as Estonia progressed along its innovation development path. Appendix 2 describes Estonia's innovation policy in more detail. The ICT infrastructure played a pivotal role in its development. When Estonia gained independence, only half of the population had a phone line. By 1997, however, $97 \%$ of Estonian schools had Internet access and by May 2013, 4G services covered over $95 \%$ of the country.

Estonia's "systemic" approach to innovation policy has produced results. In 2012 Estonia's GERD stood at $2.2 \%$ of the GDP (higher than the average across the EU-15). The percentage of GERD accounted for by the corporate sector has risen to $57 \%$, approaching the EU-15 average. Estonia was also one of the few EU countries that broadly maintained the same level of spending on public R\&D during the crisis.

In this section, we take a look at the innovation policies that transition countries currently have in place and try to assess whether these innovation policies match with their current innovation position and address the country's strength and weaknesses for an innovation-based growth.

In line with Sect. 2.4, we posit that a country's innovation policy mix should be adapted to its innovation development phase: in countries that are still lagging behind in terms of technology development, policy should foster the knowledge absorption and diffusion functions of the innovation system. A policy mix solely focussed on creative capacity may not be appropriate (yet). A country's optimal innovation policy mix not only depends on its level of innovation development and its level of key enablers for innovation-based development, but it will also be dynamically evolving along with and driving its development. Furthermore, whether any designed policy mix will be effective will depend on the quality of innovation policy governance and implementation. Rather than a one-size-fits-all, we should therefore expect heterogeneity in innovation policies across and within transition countries, not only because transition countries differ in their current position of innovation development and key enablers for innovation-based development, but also because of differences in the quality of implementation.

Information about innovation policies in transition countries comes from a 2014 EBRD-organised questionnaire for government bodies in charge of innovation policy in all transition countries. Information from the survey was supplemented with information from publicly available sources. ${ }^{8}$

A total of 18 responding transition countries are included in the analysis. The response rate was relatively high among countries at the "make and buy" stage

\footnotetext{
$\overline{8}$ See EBRD Transition Report (2014), Chapter 5, for more details.
} 


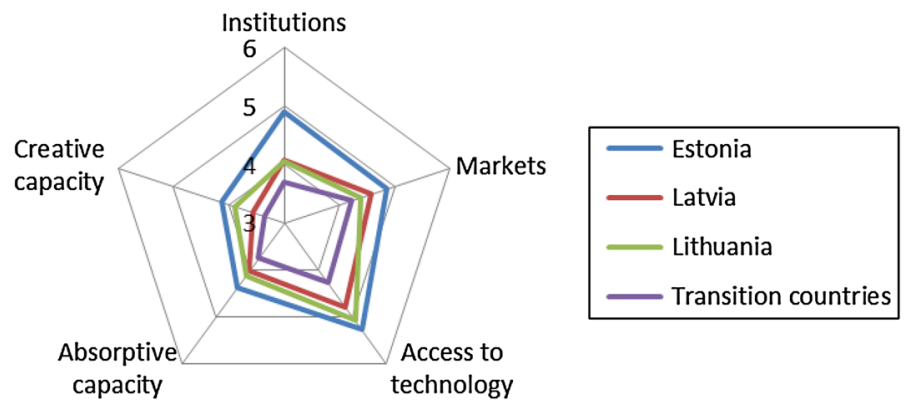

Fig. 4 Framework conditions in Estonia, Latvia and Lithuania. Source: Authors' calculations on World Economic Forum (2013). Note The scores for each indicator range from 1 to 7 , where 1 corresponds to the worst possible outcome and 7 corresponds to the best possible outcome. Scores for "macroeconomic stability" are not shown, given the extraordinary circumstances affecting this broad framework condition in the review period. Figures for the transition region are unweighted cross-country averages

(with Bulgaria, Croatia, Czech Republic, Kosovo, Latvia, Lithuania, Romania, Slovak Republic and Slovenia all replying). A similarly high response rate was seen among those at the "buy" stage (with Bosnia and Herzegovina, Hungary, the Kyrgyz Republic, Moldova, Poland, Serbia and Ukraine responding as well). In the "low innovation" category only two countries responded (Albania and Armenia). ${ }^{9}$

\subsection{Stated innovation policy objectives}

As of 2014 all countries in the transition region have drafted a nationwide policy or strategy with a view to providing public support for innovation activities. Most countries established the bulk of their policy frameworks during the 2000s. Some countries (such as Tajikistan and Turkmenistan) did not start outlining their priorities until more recently.

The survey results suggest that there is remarkably little variation across transition countries in terms of the stated objectives of innovation policy (see Fig. 5). Virtually all countries regarded the objectives of enhancing the contribution that public research organisations make to the country's innovation performance and improving the business environment for innovative firms as the most important priorities, scoring either "important" or "highly important".

Most surprisingly, the objective of better linking science and industry (measured through "enhancing the contribution of public research organisations", "improving the commercialisation of public research") is also ranked by all countries as important to highly important, even the countries in the low innovation development phase.

In contrast, the objective of providing "appropriately educated and trained people as workers, citizens, consumers and entrepreneurs", which is a critical pillar for building absorptive capacity and therefore should figure prominently for countries

\footnotetext{
9 Caution is warranted in view of this small and biased sample. Furthermore, respondents are also likely to be subjective, with a bias towards favourable assessments.
} 


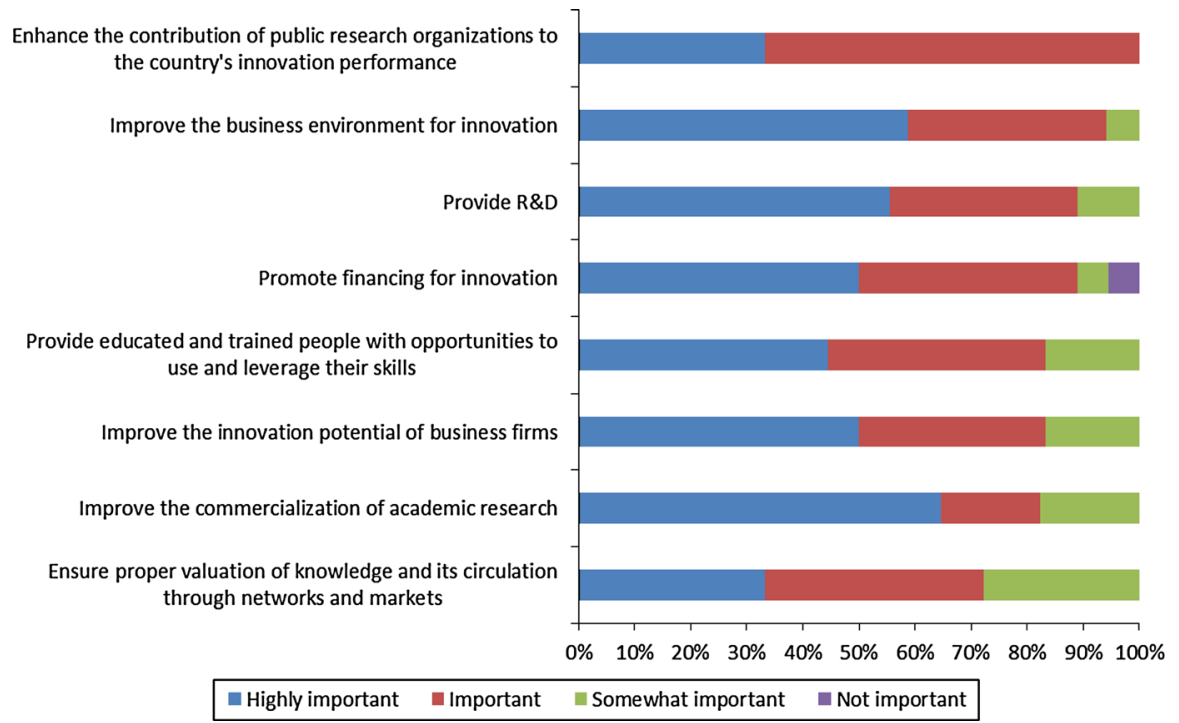

Fig. 5 Relative importance of objectives of innovation policy in transition countries. Source: EBRD innovation policy questionnaire and authors' calculations. Note The strategic objectives of innovation policy are ranked in descending order according to the percentage of countries that regard them as "highly important" or "important"

that are catching up, is rated as important, but on average below the top priorities mentioned above. Furthermore, this factor is rated lower in importance in the low innovation active countries compared to the more developed ones, while it is more critical for the former countries. ${ }^{10}$

\subsection{Innovation policy instruments}

The consensus among the transition countries extends to the preferred policy instruments for supporting innovation. The three instruments most frequently regarded as "important" or "highly important" are (1) competitive funding of $R \& D$, (2) support for the transfer of technology and (3) incentives for cooperation between industry and science (see Fig. 6).

\subsubsection{Transfer of technology and links between industry and science}

At first glance, that support for the transfer of technology appears to be well suited to the needs of emerging market economies, where the adoption of existing technology plays a prominent role. On closer inspection, however, we can see that policies primarily target the transfer of technology from science to industry. The more general technology diffusion assistance schemes score much less prominently.

\footnotetext{
10 The most frequently chosen option for this item is "very important" in the group of more advanced countries, while for the lower developed group the most frequently chosen option for this item is "important".
} 


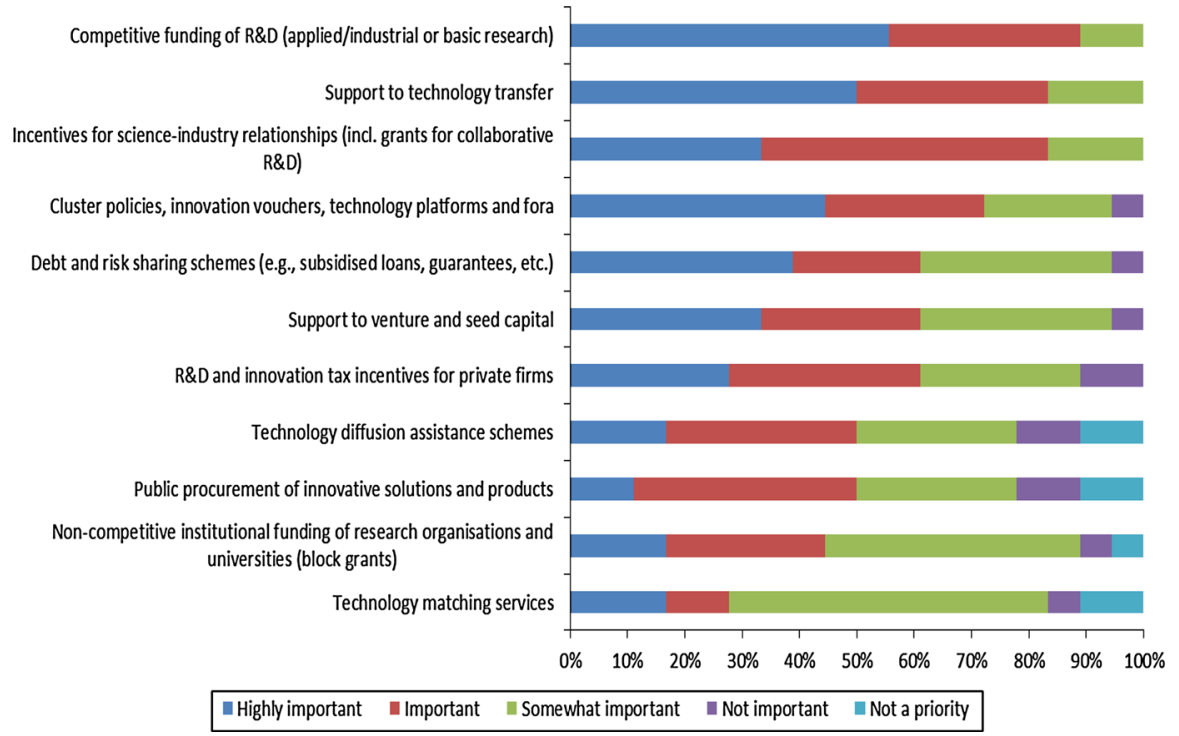

Fig. 6 Economic and financial instruments of innovation policy. Source: EBRD innovation policy questionnaire and authors' calculations. Note Economic and financial instruments of innovation policy are ranked in descending order according to the percentage of countries that regard them as "highly important" or "important"

Initiatives supporting firms' absorption of technology (assistance schemes supporting the spread of technology and technology matching services ${ }^{11}$ ) score on average only as "somewhat important". ${ }^{12}$ In contrast, incentives for science-industry relationships (including grants for collaborative R\&D) score higher on importance, in all types of countries. This suggests that technology diffusion support is mostly focussed on the supply side of industry-science links: supporting public research institutes to transfer their know-how, rather than to stimulate industry to take up public research.

Almost all countries (excluding Bulgaria) state that they have government initiatives in place targeted at stimulating transfer from research in higher education institutions and public research organisation into innovation, together with initiatives strengthening research in these institutes. This evidences the omnipresent emphasis in transition countries on public scientific institutes as key innovation actors irrespective of the innovation development of the country.

In view of the stated importance of industry-science links for innovation policies in transition countries, Appendix 3 looks at the evidence on actual industry-science link activities, using patent information. It confirms the relatively stronger presence of public research organisations in the development of applied technologies in

\footnotetext{
11 Technology matching services are web-based platforms that connect organisations offering technology with those seeking technology and technological solutions.

12 For this instrument, the most frequently reported score is "important" in the group of more advanced countries, while it is "somewhat important" in the lower developed group.
} 
transition countries, particularly in Russia, Ukraine and Poland. But the indicators also illustrate the weak links between science and industry in transition countries, with the corporate sector not using science as input for their technological inventions. The data therefore confirm that what is lacking in most transition countries-including those where the scientific community develops a lot of new technology-is a corporate sector that actively uses links with science to innovate. There is a policy bias in this regard, with countries stimulating the supply of new technology with too little regard for the demand for it from the corporate sector.

\subsubsection{Place-based policies}

Place-based innovation policies-specific measures directed at well-defined geographical areas-can be found in almost all transition countries, typically in the form of science, technology and research parks, technology centres and designated science cities. These policies provide for the direct financing of economic activities or establish special regulations governing targeted areas. They also aim to promote a culture of competitiveness and innovation among the firms located there and seek to stimulate technological spillovers.

Place-based policies are fairly popular in central Europe and the Baltic statesparticularly in Hungary, where more than 200 industrial parks can be found. They are even more popular in Russia. In a way, the former Soviet Union was a pioneer of innovation-oriented location-based policies, which were underpinned by public investment in science and fundamental research. The innovation model followed by the Soviet authorities as of the early 1930s involved the creation of "special-regime enclaves intended to promote innovation" (Cooper 2012). These enclaves initially took the form of secret research and development laboratories (referred to as Experimental Design Bureaus or, more commonly, sharashkas) in the Soviet Gulag labour camp system. In present-day Russia, 14 locations are officially designated as naukograds (science cities). In addition, the country has numerous business incubators, technology parks and technology transfer centres, as well as five special economic zones (SEZs) focussed on innovation, and the Skolkovo innovation centre (RUSSEZ 2014).

Most of these parks are linked to a specific university-Russia has almost 30 national research universities (NRUs) - and/or publicly funded research institutions, further highlighting the focus on the supply of new technology from public science, as already documented in the previous section. However, there are exceptions, such as Technopolis Pulkovo (a commercially funded science and technology park in St Petersburg), which is wholly owned by Technopolis Pulkovo, a Finnish public limited liability company. The park aims to support knowledge-intensive companies and start-ups and foster links between academia and industry, which should contribute to the diversification of the region's economy. There is also expected to be some transfer of management skills from the team of international executives overseeing the operation of the park to their local Russian colleagues.

The rationale for place-based policies stems from the expectation that they will result in localised knowledge spillovers and lead to stronger economic growth. In general, empirical evidence on the performance of science parks is mixed (see, e.g., 
Felsenstein 1994; Westhead 1997; Lindelöf and Löfsten 2003; Yang et al. 2009). There are hardly any evaluation studies of this kind for transition countries. Statistics available for Russian SEZs and innovation hubs suggest that firms located there are successful in terms of introducing new products and technologies and being granted patents and that they spend more on R\&D than other firms (EBRD 2014). However, it is impossible to know whether they would achieve the same results if they were located outside those clusters.

Most existing evaluations of place-based policies are focussed on short-term outcomes, making it difficult to judge the extent to which those policies contribute to stronger economic growth and have a more permanent impact. A recent paper looked at the impact that Soviet-era science cities - towns with a high concentration of R\&D facilities-had on firms' innovation activities (Schweiger and Zacchia 2015). The paper found that firms located in former science cities were an average of 6-9 \% points more likely to introduce new products than similar firms located elsewhere. They were also an average of 7-8 \% points more likely to introduce new processes. This impact is substantial, considering that around $13 \%$ of firms located outside former science cities were engaged in either product or process innovation. Firms located in academic towns (akademgorodoks), on the other hand, were an average of $8 \%$ points less likely to introduce new products than similar firms located elsewhere. This provides further evidence that emphasis on the supply side does not necessarily improve industry's demand for innovation or result in higher rates of product innovation among local firms.

\subsection{Design and governance of innovation policy}

Effective innovation policies rely on the careful identification of lacking conditions or key bottlenecks preventing innovation. Identifying bottlenecks requires close communication with the intended recipients of innovation support. ${ }^{13}$ It also calls for regular evaluation of the outcomes of policies. The use and effectiveness of programmes targeting innovation should not only be continuously monitored, but also benchmarked and evaluated. Future policy design phases should use the results of such evaluation exercises (Rodrik 2008).

Most countries that responded to the EBRD's innovation policy questionnaire indicated that they assess the effectiveness of spending on innovation support. However, closer inspection of published evaluation exercises suggests that such appraisals are rarely rigorous-even in the more advanced economies.

Furthermore, more than three-quarters of respondents reported that they always or usually use the continuation of existing schemes as a selection criterion when choosing instruments. There may be good reasons for this. Continuity of innovation policies increases the private sector's willingness to undertake risky investments with a long payback period. In addition, the results of innovation policies that depend on such investments may take a long time to materialise. At the same time, continuity needs to be weighed against the need to evaluate policies, learn from past mistakes and redesign policies as the economy evolves.

13 See Rodrik (2008) for a discussion of "embeddedness" as a key feature of policy design. 
The effectiveness of innovation policies also depends on the overall quality of governance in the countries that implement them. In this regard it is telling that only five survey respondents reported that they never use ad hoc selection criteria or take account of the lobbying activities of particular groups.

Weak governance may be particularly damaging when it comes to identifying priority sectors and the allocation of related subsidies and concessions. In general, governments tend not to be particularly good at picking winners, and identifying losers has proven politically difficult. Authorities in countries with weak governance are likely to have particularly poor track records in these areas.

\subsection{Sectoral targeting in innovation policies}

Transition economies have a long history of attempting policies aimed at specific sectors or technologies. Nevertheless, vertical innovation policies require high standards of governance to be effective, so they may not suit most transition economies. Broader sectoral coverage may be particularly advantageous for countries in the early stages of development. Their existing innovation capacity in any specific field is typically too weak to warrant a clear focus based on indigenous strengths. In contrast, broader support for multiple sectors may help to strengthen the general innovation capacity of countries, with strong competitive positions in specific areas being developed over time.

While most of these countries do not focus their public support on a single sector, they do tend to identify a few priority areas. As with other features of innovation policy in the region, countries tend to focus on similar priority areas (see Fig. 7).

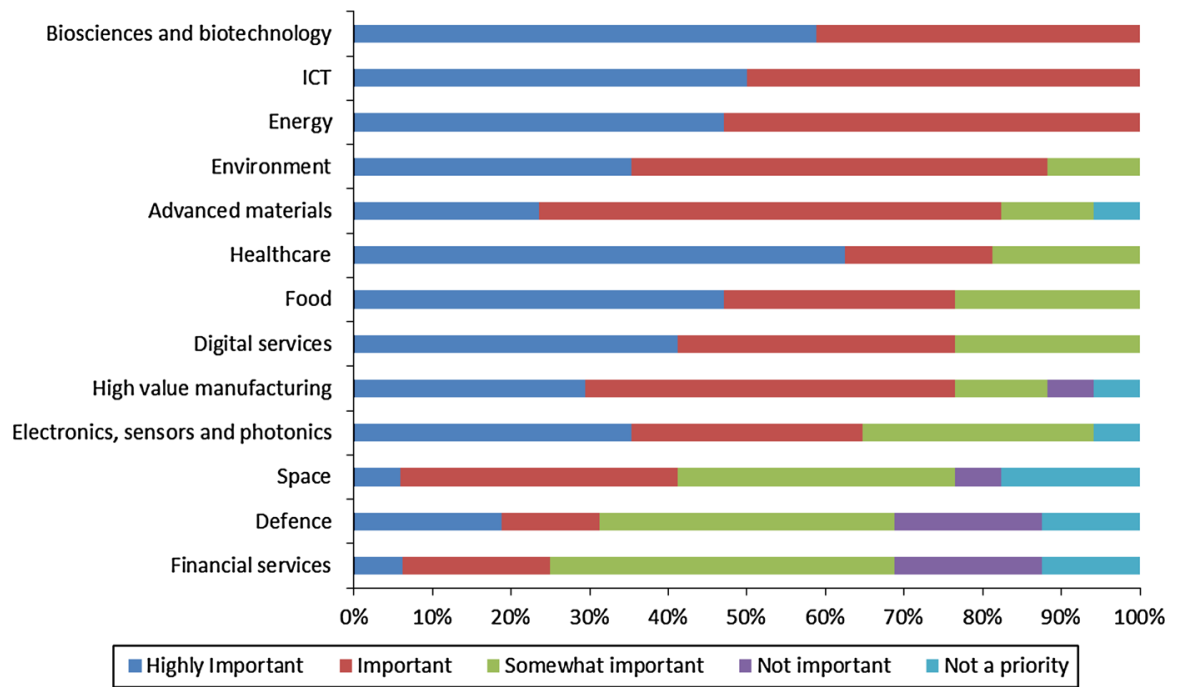

Fig. 7 Priority areas for innovation spending. Source: EBRD innovation policy questionnaire and authors' calculations. Note Priority areas for innovation spending are ranked in descending order according to the percentage of countries that regard them as "highly important" or "important" 
They show little variation based on their individual circumstances, the existing structure of production or their skills mix. They do not identify priority areas on the basis of careful analysis of their strengths and comparative advantages. ${ }^{14}$

All transition countries regard biosciences and biotechnology, ICT and energy as "highly important" or "important" priority areas for public innovation spending. Other sectors that are at least "somewhat important" in all countries are the environment, healthcare, food and digital services.

Some country-specific priorities include the energy sector in Kazakhstan, Turkmenistan and Ukraine. Belarus and Kazakhstan place emphasis on heavy industries, building on their legacy from the Soviet era.

The ICT sector is prioritised virtually across the board in transition countries, consistent with its general purpose characteristics. Nevertheless, it is more targeted in some countries than in others. Estonia's successful ICT focus was already discussed in Appendix 2. ICT is also a particularly strong focus in Armenia and Azerbaijan, both of which singled it out as a driver of growth in the early 2000s. However, both countries have used different approaches to support the development of the ICT sector and have made progress at different speeds (see Appendixes 4, 5).

\section{Conclusions: which size fits innovation policies in transition countries?}

The analysis in this contribution shows that transition countries at different stages of development differ in terms of their ability to use and create knowledge. This ability is shaped by the quality of institutions and the functioning of product, labour and financial markets. It is also determined by specific country conditions underpinning firms' ability to effectively access and absorb existing technology and create new technology.

Despite the underlying differences in transition countries' potential for innovation-based growth and the ways in which their firms tend to acquire knowledge, transition countries have surprisingly similar innovation policies. This indicates that the stated policy targets and instrument mixes are, in most cases, insufficiently tailored to the specific circumstances of these countries. Innovation policy mixes are an outcome of a variety of factors and only one of these is their distance to the technological frontier. Other factors are policy fashions and perceptions of one-sizefits-all best practices in innovation policy. In particular, innovation policies in the region tend to follow trends set by advanced economies, focussing on the conditions for creative capacity rather than absorptive capacity.

\footnotetext{
14 Tödtling and Trippl (2005) and the European Commission (2013) both come to a similar conclusion regarding EU member states. European Commission exercises such as the National Reform Programmes, the European Semester and smart specialisation programmes tend to heavily influence the innovation policies of transition countries in the EU. Member States are aligning their innovation policies to the EU innovation policy framework as specified in the Innovation Union Flagship and the Horizon 2020, targeting similar "grand challenges" and associated science and technology areas, focussing on improving creative capacity and better connecting innovation actors.
} 
Perhaps the clearest illustration of this is the overarching focus in all transition countries on developing high-tech industries and improving the contribution that public research organisations make to innovation performance. The importance of enhancing the contribution of public research institutes to innovation as an objective of innovation policies and the presence of financial stimuli for promoting industryscience collaboration holds in all transition countries, reflecting their legacy of strong public science-dominated innovation systems. This undifferentiated focus of innovation policy on the industry-science links and the focus on stimulating the supply of science-based technology rather than the demand from industry does not square with the heterogeneity among transition counties in the strength of their public research institutes and the capacity of their firms to use public science for their absorptive and creative capacity.

This kind of one-size-fits-all approach may not suit most transition countries. In extreme cases, simply taking innovation policies that are designed for advanced economies and transposing them to transition countries may be more of a deterrent rather than acting as a catalyst for knowledge-based growth. Given that these countries are not yet operating at the technological frontier, governments need to focus more on supporting the absorption and adaptation of the existing cutting-edge technology, which feature far less prominently in current innovation policy programmes as a priority. Similarly, greater attention needs to be paid to improving the formation of human capital in universities, which often focusses excessively on academic patenting rather than educating and training the future entrepreneurs and workforce. As countries develop and approach the technological frontier, innovation policies need to evolve, gradually placing greater emphasis on helping firms to improve their capacity to create knowledge.

The design and governance of innovation policy in transition countries is highly complex, as policy instruments and priority areas need to be tailored to the specific circumstances of countries and adjusted as the country develops further along its innovation-based growth path. This is perhaps the greatest challenge for innovation policy in transition countries. The innovation policy system should ensure maximum transparency when allocating innovation support. Policy instruments need to include clear conditionalities linked to addressing the bottlenecks identified. They should also specify exit strategies to mitigate the risk of firms becoming addicted to support.

Policies should be subject to regular evaluations, with reviews linked to those evaluations. Thus, the design and implementation of effective innovation policies require a sophisticated public administration with the capacity to regularly evaluate a country's strengths and weaknesses and collect the data necessary to conduct such assessments. This calls for the quality of public administration to be improved in the area of innovation policy, for instance by providing universities with the resources and incentives needed to properly train future civil servants. That may in itself be an important aspect of a country's innovation policy mix.

Innovation policy requires striking an appropriate balance between horizontal and vertical policy elements. To be effective, vertical innovation policies focussing on support for particular sectors require high standards of governance and highquality economic institutions. Given the weak economic institutions in many 
transition countries, such policies may not suit most of them. The high risk of manipulation by interest groups may outweigh the potential benefits of more targeted support. It would be better to initially prioritise improvements in institutional quality and address common bottlenecks affecting innovation in all sectors. Effective horizontal policies that address bottlenecks affecting innovation (such as corruption, inadequate skills among the workforce, and customs and trade regulations) help firms in all sectors, including those identified as priorities. Effective horizontal policies are often a prerequisite if vertical policies are to yield positive results. In this regard, improving access to ICT can in fact be seen as an important horizontal policy aimed at improving the productivity of firms in all sectors that actively use ICT technologies.

Where countries decide to make active use of vertical policies providing benefits and subsidies to specific sectors or firms, targeting of particular sectors or firms needs to be based on strict eligibility criteria in order to minimise rent-seeking behaviour by firms and officials (see, e.g., Rodrik 2008; Aghion et al. 2012, 2014). These criteria include comparative strengths of the country in the targeted sector, potential benefits for the broader economy and the degree of competition within the sector. All too often targeting is focussed on cutting edge innovation in fashionable high-tech sectors, while a transition country's strengths may lie in the application of cutting-edge technology in medium- or low-tech sectors, such as food or textiles. These sectors are often overlooked by innovation policies, but they may deliver sizeable returns to innovation when countries hold comparative advantages in these sectors.

\section{Appendix 1}

See Table 1.

Table 1 Key prerequisites for knowledge-based growth

\begin{tabular}{|c|c|c|}
\hline $\begin{array}{l}\text { Composite } \\
\text { factors }\end{array}$ & Individual factors & Description \\
\hline Institutions & Institutions & $\begin{array}{l}\text { Public institutions ( } 75 \% \text {-property rights, ethics and } \\
\text { corruption, undue influence, government efficiency, } \\
\text { security) and private institutions }(25 \% \text {-corporate } \\
\text { ethics, accountability) }\end{array}$ \\
\hline $\begin{array}{l}\text { Macroeconomic } \\
\text { environment }\end{array}$ & $\begin{array}{c}\text { Macroeconomic } \\
\text { environment }\end{array}$ & $\begin{array}{l}\text { Government budget balance, gross national savings, } \\
\text { inflation, government debt, country's credit rating }\end{array}$ \\
\hline \multirow[t]{4}{*}{ Markets } & $\begin{array}{l}\text { Goods market } \\
\text { efficiency }\end{array}$ & $\begin{array}{l}\text { Competition (67\%-domestic competition and foreign } \\
\text { competition) and quality of demand conditions (33\%) }\end{array}$ \\
\hline & $\begin{array}{l}\text { Labour market } \\
\text { efficiency }\end{array}$ & Efficiency $(50 \%)$ and efficient use of talent $(50 \%)$ \\
\hline & $\begin{array}{l}\text { Financial market } \\
\text { development }\end{array}$ & $\begin{array}{l}\text { Efficiency }(50 \%) \text { and trustworthiness and confidence } \\
\quad(50 \%)\end{array}$ \\
\hline & Market size & \\
\hline
\end{tabular}


Table 1 continued

\begin{tabular}{ll}
\hline $\begin{array}{l}\text { Composite } \\
\text { factors }\end{array}$ & Individual factors \\
& $\begin{array}{c}\text { Intensity of local } \\
\text { competition }\end{array}$ \\
& Proclivity to trade ${ }^{\mathrm{a}}$ \\
& $\begin{array}{c}\text { Prevalence of foreign } \\
\text { ownership }\end{array}$ \\
& $\begin{array}{c}\text { Days to start business } \\
\text { a }\end{array}$ \\
Access to & $\begin{array}{c}\text { Availability of latest } \\
\text { technologies }\end{array}$
\end{tabular}

ICT availability/use

FDI and technology transfer

Absorptive capacity

Secondary enrolment

Quality of the educational system

Extent of staff training

"Brain drain"

Tertiary enrolment

Creative "Brain drain"
capacity

Tertiary enrolment

\section{Availability of scientists and engineers}

Quality of scientific research institutions

\section{Description}

Summarises information about domestic market size and foreign market size

In your country, how intense is the competition in the local market? $(1=$ not intense at all; $7=$ extremely intense $)$

Imports and exports as a percentage of GDP (hard data; simple average rescaled to $1-7$ )

How prevalent is foreign ownership of companies in your country? $(1=$ very rare; $7=$ highly prevalent $)$

Number of days required to start a business (hard data; rescaled to 1-7)

In your country, to what extent are the latest technologies available? $(1=$ not available at all; $7=$ extremely available)

Internet users, broadband Internet subscriptions, Internet bandwidth, mobile broadband subscriptions, mobile telephone subscriptions, fixed telephone lines

To what extent does FDI bring new technology into your country? $(1=$ not at all; $7=$ to a great extent $)$

Gross secondary education enrolment rate (hard data; rescaled to 1-7)

How well does the educational system in your country meet the needs of a competitive economy? $(1=$ not well at all; $7=$ extremely well)

In your country, to what extent do companies invest in training and employee development? $(1=$ not at all; $7=$ to a great extent)

Does your country attract talented people from abroad? ( $1=$ not at all; $7=$ attracts the best and brightest from around the world). Does your country retain talented people? $(1=$ The best and brightest leave to pursue opportunities in other countries. $7=$ The best and brightest stay and pursue opportunities in this country)

Gross tertiary education enrolment rate (hard data; rescaled to $1-7$ )

Does your country attract talented people from abroad? $(1=$ not at all; $7=$ attracts the best and brightest from around the world). Does your country retain talented people? $(1=$ The best and brightest leave to pursue opportunities in other countries. $7=$ The best and brightest stay and pursue opportunities in this country)

Gross tertiary education enrolment rate (hard data; rescaled to $1-7$ )

In your country, to what extent are scientists and engineers available? $(1=$ not at all; $7=$ widely available $)$

In your country, how would you assess the quality of scientific research institutions? $(1=$ extremely poor among the worst in the world; $7=$ extremely good among the best in the world) 
Table 1 continued

\begin{tabular}{|c|c|c|}
\hline \multirow{4}{*}{$\begin{array}{l}\text { Composite } \\
\text { factors }\end{array}$} & Individual factors & Description \\
\hline & $\begin{array}{l}\text { University-industry } \\
\text { research } \\
\text { collaboration }\end{array}$ & $\begin{array}{l}\text { In your country, to what extent do business and universities } \\
\text { collaborate on research and development (R\&D)? } \\
(1=\text { do not collaborate at all; } 7=\text { collaborate } \\
\text { extensively) }\end{array}$ \\
\hline & $\begin{array}{l}\text { Intellectual property } \\
\text { protection }\end{array}$ & $\begin{array}{l}\text { In your country, how strong is the protection of intellectual } \\
\text { property, including anti-counterfeiting measures? } \\
(1=\text { extremely weak; } 7=\text { extremely strong })\end{array}$ \\
\hline & $\begin{array}{l}\text { Venture capital } \\
\text { availability }\end{array}$ & $\begin{array}{l}\text { In your country, how easy is it for entrepreneurs with } \\
\text { innovative but risky projects to find venture capital? } \\
(1=\text { extremely difficult; } 7=\text { extremely easy) }\end{array}$ \\
\hline
\end{tabular}

\footnotetext{
${ }^{a}$ These variables are also represented in the composite goods market efficiency indicator, but they are nevertheless also introduced separately to increase their weight in the Markets indicator
}

Source: Veugelers (2011)

\section{Appendix 2: Estonia's innovation policy}

Estonia's innovation policy formally began in 2000 with discussions regarding the first Knowledge-Based Estonia (KBE) strategy, which covered the period 2002-2006. This strategy drew on the experiences of Finland and Sweden (see, e.g., OECD 2010; Polt et al. 2007), taking account of specific development opportunities, the existing research potential and the country's economic structure, as well as other Estonian development strategies, most notably its education policy strategy "Learning Estonia". The two main objectives were updating Estonia's knowledge pool and increasing the competitiveness of its companies. The three key areas for Estonian research, development and innovation (RDI) were (1) userfriendly information technology and the development of an information society; (2) biomedicine; (3) material technology (see KBE 2002-06).

In order to achieve these objectives, the KBE strategy established a set of measures spanning four key areas: financing of R\&D, development of human capital, increasing the effectiveness of RDI systems and international cooperation. These measures sought to increase gross domestic expenditure on R\&D (GERD) to $1.5 \%$ of the GDP by 2006. They also aimed to rebalance the expenditure on research versus development, seeking to shift the breakdown between the two from 90:10 to 60:40 by 2006. To increase the effectiveness of its RDI system, Estonia adopted location-based policies, creating science parks and regional business incubators. Lastly, Estonia used international cooperation not only as a means of attracting foreign knowledge and technology, but also as a way of building research teams with critical mass and avoiding "brain drain".

The KBE strategy for the 2002-2006 period was followed by similar strategies for the 2007-2013 and 2014-2020 periods. A number of governmental and independent bodies have conducted assessments looking at the progress made under the first two strategies. Each strategy has taken account of the experience and expert recommendations resulting from the preceding period and set more ambitious objectives, with targets increasing in number and scope. The key areas have been 
adjusted over time, but the overall priorities have not. The focus continues to be on ICT, health technology and services, and more efficient use of resources. ${ }^{15}$

Private-sector involvement helped to strengthen publicly funded education and training programmes. The Estonian Association of Information Technology and Telecommunications (EAITT), an industry association, played a leading role in the development of clusters and the design of vocational and university education programmes (see OECD 2013). The EAITT is responsible for several initiatives, including the Ustus Agur Scholarship (which is awarded to a doctoral student working in the field of ICT at a public university) and the Idea of the Year (which celebrates ideas or projects that have had a particularly strong impact on the field of ICT).

\section{Appendix 3: Industry-science links in transition countries}

To empirically assess industry-science links in transition countries, we use information from publications and patent applications. The use of publication and patent information has the advantage that it relies on publicly available databases of high reliability, which cover all countries across a long time horizon, rather than subjective, ad-hoc surveys, such as the WEF indicators. The disadvantage is however that it only covers a narrow part of industry-science links as it only measures them when reflected in publications and/or patents, which is a very narrow focus, likely not representing the majority of industry-science links. ${ }^{16,17}$

Several industry-science link indicators can be constructed using patent and publication information. We will use the following: (1) patents with universities or public research organisations (HEI/PRO) as applicants; (2) co-patenting between industry and science (i.e. applicants include both corporates as well as HEI/PROs); (3) corporate patents with scientific non-patent references, i.e. corporate patents that refer to scientific literature used as prior art for their inventions. While the first measure reflects the supply/science focus of industry-science links, the latter measure reflects the demand/industry focus of industry-science links.

Overall the stock of patent applications of the transition countries in the considered period (2000-2010) is small, representing less than $10 \%$ of the patents applied for by US applicants. Russia is the major patenting transition country (with $42 \%$ of all transition county patents). ${ }^{18}$

Table 2 reports industry-science link indicators based on patent data for the major patenting transition countries. The results for the USA, Germany and Israel are also reported as a benchmark.

In the USA only $6 \%$ of patents are held by universities or public organisations compared with $15 \%$ in the transition region. In fact, in Russia, Poland and Ukraine

\footnotetext{
15 See EBRD Transition Report (2014), Chapter 5, for more details.

${ }^{16}$ For a more elaborate discussion and analysis of industry-science link indicators based on patents, see Veugelers et al. (2012).

17 The BEEPS innovation module reports that on average in BEEPS countries, only $5 \%$ of innovation active firms applied for patents.

18 In case of multiple countries as applicants, the data are not fractioned.
} 
Table 2 Industry-science link indicators based on patent applications for transition countries

\begin{tabular}{lcllr}
\hline & $\begin{array}{l}\text { Total } \\
\text { patent } \\
\text { stock (in } \\
\text { 000) }\end{array}$ & $\begin{array}{l}\text { Share of patents } \\
\text { with HEI/PRO as } \\
\text { applicant (\%) }\end{array}$ & $\begin{array}{l}\text { Share of patents with } \\
\text { HEI/PRO and corporate } \\
\text { co-applicants (\%) }\end{array}$ & $\begin{array}{l}\text { Share of corporate patents } \\
\text { with scientific non-patent } \\
\text { references (\%) }\end{array}$ \\
\hline USA & 2875 & 6 & 0.2 & 10 \\
Germany & 1458 & 3 & 0.2 & 5 \\
Israel & 58 & 13 & 0.4 & 10 \\
Russia & 115 & 33 & 2.4 & 1 \\
Ukraine & 42 & 43 & 2.2 & 1 \\
Poland & 32 & 37 & 0.4 & 3 \\
Czech & 22 & 8 & 0.3 & 2 \\
Republic & & & 0.5 & 7 \\
Hungary & 17 & 1 & 0.1 & 4 \\
Slovenia & 6 & 7 & 2.0 & 6 \\
Estonia & 2 & 8 & &
\end{tabular}

Source: Authors' calculations on the basis of PATSTAT. Note All patent applications reported in PATSTAT with country as applicant. Period covered is 2000-2010. Patents are classified in sector (HEI Higher Education Institutes, PRO Public Research Organisations) on the basis of the methodology developed by the KU Leuven (see European Commission 2011 for more details)

over a third of all patents are held by universities or research institutes. This reflects the persistent legacy of centralised state-led research.

Furthermore, while co-patenting involving academia and industry is relatively rare everywhere, its incidence in the transition region is relatively high by comparison with the USA. Russia stands out in this regard, accounting for $62 \%$ of all co-patenting in the transition region. This suggests that universities and research institutes have a high degree of involvement in the development of technology, especially in Russia. Consequently, links between industry and science in transition countries such as Russia mostly involve the scientific community supplying new technology to industry.

The picture is dramatically different when looking at such links from the perspective of corporate demand-in other words, when looking at how often corporate patents refer to scientific literature (scientific non-patent references) as prior art for patented inventions. When assessed on the basis of this indicator, Russia and Ukraine score very poorly. Slovenia, Hungary and Estonia, on the other hand, score much better than other major patenting countries in the transition region, albeit they still lag behind the USA. Israel scores almost as highly as the USA on this indicator.

\section{Appendix 4: ICT targeting in Armenia}

Armenia was one of the major $\mathrm{R} \& \mathrm{D}$ and production centres for computer science, electronics, precision engineering and chemicals in the former Soviet Union (EV Consulting 2010). When many of those industries were shut down in the early 
1990s, a number of highly qualified professionals emigrated and established companies abroad. However, they then contributed to the rise of the local ICT industry by creating development centres back home in Armenia. In 2000 the government recognised the ICT sector's potential and declared its development a national priority. In 2002 it established the Enterprise Incubator Foundation (EIF), a one-stop support agency for innovative ICT companies. The agency delivers business and workforce development services, along with consultancy services and legal and financial support, with a focus on start-ups. ${ }^{19}$ The EIF has conducted several projects with international ICT companies, including firms with no specific ties to the Armenian diaspora. ${ }^{20}$

The ICT and high-tech sectors are among the fastest growing industries in Armenia. The number of ICT companies in Armenia has grown from around 175 in 2008 to around 380 in 2013 . What is more, in 2011 exports accounted for $44 \%$ of those firms' revenues. However, the development of the ICT sector is being constrained by a shortage of skilled labour with IT training. Several initiatives have been devised in order to overcome this problem. They include Sun Training Labs, a project established by the EIF, Sun Microsystems Inc. and USAID, with a view to strengthening the skills of university graduates, and the Synopsys Armenia Educational Department, which provides training in microelectronics in partnership with major Armenian universities (EV Consulting 2014).

\section{Appendix 5: ICT targeting in Azerbaijan}

Azerbaijan focussed mostly on improving the ICT infrastructure, resulting in communications networks being completely digitalised and the capacity of external Internet channels being increased. The liberalisation of the telecommunications market has opened up opportunities for the private sector and tariffs for unlimited broadband Internet have plummeted. Total investment in ICT-both state and private investment-more than doubled between 2009 and 2011. A number of other initiatives have been carried out in recent years. Azerbaijan's high-technology park was launched in 2012. The country branded 2013 "The Year of ICT" and launched its Online Presence Project, which seeks to improve the accessibility of government and public institutions, as well as private companies, via online channels. In July 2014 the State Fund for the Development of IT, which was established in 2012, awarded grants to 31 start-up projects in areas such as high-technology, e-payment software applications, air navigation systems and e-government.

\footnotetext{
19 In 2013, for example, the EIF organised the Innovation Matching Grants Competition, which offered grants of up to US\$50,000 to innovative SMEs and start-ups.

20 See UNECE (2014). Examples include Synopsys, National Instruments and D-Link International. Other notable examples include the launch of the Cisco Systems Networking Academy Program in 2010, which fosters computer and software penetration in business and education, and the launch of the Microsoft Innovation Center in 2011, which provides resources and infrastructure to SMEs and start-ups in the ICT sector.
} 


\section{References}

Abramovitz M (1986) Catching up, forging ahead and falling behind. J Econ Hist 46(2):386-406

Acemoğlu D, Aghion P, Zilibotti F (2006) Distance to frontier, selection, and economic growth. J Eur Econ Assoc 4(1):37-74

Aghion P, Askenazy P, Bourles R, Cette G, Dromel N (2009a) Education, market rigidities and growth. Econ Lett 102(1):62-65

Aghion P, Boustan L, Hoxby C, Vandenbussche J (2009b) The causal impact of education on economic growth: Evidence from U.S. Brookings Papers on Economic Activity, Spring 2009

Aghion P, Dewatripont M, Du L, Harrison A, Legros P (2012) Industrial policy and competition. Mimeo. http://scholar.harvard.edu/files/aghion/files/industrial_policy_and_competition.pdf. Last Accessed 15 Sept 2014

Aghion P, Bechtold S, Cassar L, Herz H (2014) The causal effects of competition on innovation: Experimental evidence. Mimeo. http://scholar.harvard.edu/files/aghion/files/causal_effects_of_ competition.pdf. Last Accessed 16 Sept 2014

Aitken B, Harrison A (1999) Do domestic firms benefit from foreign direct investment? Evidence from Venezuela. Am Econ Rev 89(3):605-618

Blomström M, Kokko A (1998) Multinational corporations and spillovers. J Econ Surv 12(3):247-277

Carlin W, Schaffer M, Seabright P (2004) A minimum of rivalry: Evidence from transition economies on the importance of competition for innovation and growth. Contrib Econ Anal Policy 3(1):1284

Cohen WM, Levinthal DA (1989) Innovation and learning: The two faces of R\&D. Econ J 99(397):569-596

EV Consulting (2010) The story of the emerging IT cluster in Armenia. http:/evconsulting.com/sites/ default/files/CASE\%20STUDY-IT_2010\%20Revised_Final-130312.pdf. Last Accessed 17 Sept 2014

EV Consulting (2014) National Competitiveness Report of Armenia 2013-2014: Growth Imperative and Constraints. http://evconsulting.com/sites/default/files/attachments/pdf/ACR\%202014\%20eng.pdf. Last Accessed 17 Sept 2014

Cooper JM (2012) Science-technology policy and innovation in the USSR. Slides from the CEELBAS Workshop "Russia's Skolkovo in comparative and historical perspective", held on 12 June 2012 at UCL SSEES

Damijan JP, Knell M, Majcen B, Rojec M (2003) The Role of FDI, R\&D accumulation and trade in transferring technology to transition countries: Evidence from firm panel data for eight transition countries. Econ Syst 27(2):189-204

Dyker D, Radošević S (eds) (1999) Innovation and structural change in post-socialist countries: A quantitative approach. Springer, New York

EBRD (2013) Transition report 2013: Stuck in Transition? London

EBRD (2014) Transition report 2014: Innovation in Transition. London

European Commission (2011) Patent statistics at Eurostat: Methods for regionalisation, sector allocation and name harmonisation. Eurostat Methodologies and Working Papers, KS-RA-11-008

European Commission (2013) Lessons from a decade of innovation policy. What can be learnt from the INNO Policy Trend Figure and the Innovation Union Scoreboard?. http://ec.europa.eu/DocsRoom/ documents/5220/attachments/1/translations/en/renditions/pdf. Last Accessed 8 Oct 2014

Fagerberg J, Srholec M (2008) National innovation systems, capabilities and economic development. Res Policy 37(9):1417-1435

Fagerberg J, Knell M, Srholec M (2007) The competitiveness of nations: Why some countries prosper, while others fall behind. World Dev 35(10):1595-1620

Felsenstein D (1994) University-related science parks-'seedbeds' or 'enclaves' of innovation? Technovation 14(2):93-110

Furman JL, Porter ME, Stern S (2002) The determinants of national innovation capacity. Res Policy 31(6):899-933

Görg H, Greenaway D (2004) Much ado about nothing? Do domestic firms really benefit from FDI? World Bank Res Obs 19(2):171-197

Gorodnichenko Y, Svejnar J, Terrell K (2010) Globalisation and innovation in emerging markets. Am Econ J Macroecon 2(2):194-226

Hoekman B, Maskus K, Saggi K (2005) Transfer of technology to developing countries: Unilateral and multilateral policy options. World Dev 33(10):1587-1602 
Hoekman B, Smarzynska Javorcik B (eds) (2006) Global integration and technology transfer. Palgrave MacMillan, New York

Keller W (2004) International technology diffusion. J Econ Lit 42(3):752-782

Kristapsons J, Martinson H, Dagyte I (2003) Baltic R\&D systems in transition: Experiences and future prospects, Zinātne, Riga. www.lza.lv/csts/Baltic_R\&D_Systems.pdf. Last Accessed 15 Sept 2014

Lall S (1992) Technological capabilities and industrialisation. World Dev 20(2):165-186

Lindelöf P, Löfsten H (2003) Science park location and new technology-based firms in Swedenimplications for strategy and performance. Small Bus Econ 20(3):245-258

Markusen J, Venables A (1999) Foreign direct investment as a catalyst for industrial development. Eur Econ Rev 43(2):335-356

Mazzoleni P, Nelson RR (2007) Public research institutions and economic catch-up. Res Policy 36(10):1512-1528

Narula R, Dunning JH (2000) Industrial development, globalisation and multinational enterprises: New realities for developing countries. Oxf Dev Stud 28(2):141-167

Nelson R (1993) National innovation systems: A comparative analysis. Oxford University Press, New York

Nunn N, Trefler D (2010) The structure of tariffs and long-term growth. Am Econ J Macroecon 2(4):158-194

OECD (2010) OECD Science, Technology and Industry Outlook 2010, Paris. http://www.oecd.org/sti/ inno/oecdsciencetechnologyandindustryoutlook2010.htm

OECD (2013) Innovation-driven growth in regions: the role of smart specialisation. Preliminary version, Paris. http://www.oecd.org/sti/inno/smart-specialisation.pdf. Last Accessed 10 June 2015

Polt W, Koch P, Wolters A (2007) Evaluation of Estonian RTDI policy mix. Innovation studies, No. 10. http://www.fteval.at/upload/Evaluation_of_Estonian_RTDI_Policy_Mix.pdf. Last Accessed 10 June 2015

RINDICATE (2007) The role of science and technology for catching-up economics. Report prepared for EC-RTD, coordinated by Idea Consult

Rodrik D (2008) Normalizing industrial policy. Commission on Growth and Development working paper No. 3. www.sss.ias.edu/files/pdfs/Rodrik/Research/normalizing-industrial-policy.pdf. Last Accessed 1 Sept 2014

RUSSEZ (2014) Innovation zones. http://eng.russez.ru/oez/innovation/. Last Accessed 1 Sept 2014

Schweiger H, Zacchia P (2015) Are science cities fostering firm innovation?. Evidence from Russia's regions, Mimeo

Tödtling F, Trippl M (2005) One size fits all? Towards a differentiated regional innovation policy approach. Res Policy 34(8):1203-1219

UNECE (2014) Innovation performance review of Armenia. New York and Geneva

Verspagen B (1991) A new empirical approach to catching up or falling behind. Struct Change Econ Dyn 2(2):359-380

Veugelers R (2011) Assessing the potential for knowledge-based development in the transition countries of Central and Eastern Europe, the Caucasus and Central Asia. Soc Econ 33(3):475-501

Veugelers R, Cakkaert J, Song X, Van Looy B (2012) The participation of universities in technology development: do creation and use coincide? An empirical investigation on the level of national innovation systems. Econ Innov New Technol 21(5-6):445-472

Westhead P (1997) R\&D 'input' and 'output' of technology-based firms located on and off science parks. R\&D Manag 27(1):45-62

World Bank (2008) Global Economic Prospects 2008: Technology diffusion in the developing world. Washington, DC

World Economic Forum (2013) The Global Competitiveness Report 2013-2014. Geneva

Yang C-H, Motohashi K, Chen J-R (2009) Are new technology-based firms located on science parks really more innovative? Evidence from Taiwan. Res Policy 38(1):77-85 
Reproduced with permission of the copyright owner. Further reproduction prohibited without permission. 